\title{
Factors associated with death in children with COVID-19 in Mexico
}

\author{
Rodolfo Rivas-Ruiz, ${ }^{1}$ Ivonne A. Roy-García, ${ }^{1 *}$ Kingston R. Ureña-Wong, ${ }^{2}$ Felipe Aguilar-Ituarte, ${ }^{3}$ \\ Gilberto F. Vázquez-de Anda, ${ }_{4}^{4}$ Pedro Gutiérrez-Castrellón, ${ }^{5}$ Javier Mancilla-Ramírez ${ }^{6}$ and \\ Sarbelio Moreno-Espinosa ${ }^{7}$ \\ ${ }^{1}$ Center for Training in Clinical Research, Research Development Division, Instituto Mexicano del Seguro Social, Mexico City; ${ }^{2}$ Teaching Coordination, \\ Asociación para Evitar la Ceguera en México, Mexico City; ${ }^{3}$ Private practice, Mexico City; ${ }^{4}$ Faculty of Medicine, Universidad Autónoma del Estado \\ de México, State of Mexico; ${ }^{5}$ Center for Translational Research in Health Sciences, Hospital "Dr. Manuel Gea González", Secretaría de Salud, \\ Mexico City; ${ }^{6} \mathrm{Health}$ Quality and Education, Secretaría de Salud, Mexico City; ${ }^{7}$ Hospital Infantil de México "Federico Gómez", Secretaría de Salud, \\ Mexico City. Mexico
}

\begin{abstract}
Introduction: Most children affected by SARS-CoV-2 are reported to be asymptomatic, and COVID-19-related mortality in them is low; in Mexico, there is a lack of information on the subject in this population group. Objective: To assess the risk factors associated with mortality in Mexican children with COVID-19. Method: Secondary analysis of the General Directorate of Epidemiology database. Children younger than 19 years, in whom SARS-CoV-2 infection was confirmed by RT-PCR, were included. Results: 1443 children were included. Median age was eight years; $3.3 \%$ were admitted to the intensive care unit, $1.8 \%$ required assisted mechanical ventilation, and mortality was $1.9 \%$. In multivariate models, the development of pneumonia was the main risk factor for mortality, with an odds ratio (OR) of 6.45 (95\% Cl: 1.99, 20.89); patients who required intubation had an OR of 8.75 (95 \% Cl: 3.23, 23.7). Conclusions: Children with COVID-19 exhibit high mortality in Mexico, and avoiding pneumonia should therefore be tried in them, especially in children younger than four years, with cardiovascular risk or immunosuppression.
\end{abstract}

KEY WORDS: Coronavirus disease 2019. Children. Mortality. Risk factors. Pneumonia.

\section{Factores asociados a muerte en niños con COVID-19 en México}

\section{Resumen}

Introducción: Se informa que la mayoría de los niños afectados por SARS-CoV-2 cursan asintomáticos y que en ellos la mortalidad por COVID-19 es baja; en México se desconoce la información al respecto en este grupo de la población. Objetivo: Evaluar los factores de riesgo asociados a mortalidad en niños mexicanos con COVID-19. Método: Análisis secundario de la base de datos de la Dirección General de Epidemiología. Se incluyeron niños menores de 19 años, en quienes se confirmó SARS-CoV-2 mediante RT-PCR. Resultados: Se incluyeron 1443 niños. La mediana de edad fue de ocho años; $3.3 \%$ ingresó a la unidad de cuidados intensivos, $1.8 \%$ requirió ventilación mecánica asistida y la mortalidad fue de 1.9 \%. En los modelos multivariados, el desarrollo de neumonía constituyó el principal factor de riesgo de mortalidad, con razón de momios (RM) de 6.45 (IC 95 \% 1.99, 20.89); los pacientes que requirieron intubación tuvieron RM de 8.75 (IC 95 \% 3.23, 23.7). Conclusiones: Los niños con COVID 19 tienen alta mortalidad en México, por lo que en ellos se debe procurar evitar la neumonía, especialmente en los menores de cuatro años, con riesgo cardiovascular o inmunosupresión.

PALABRAS CLAVE: Enfermedad por coronavirus 2019. Niños. Mortalidad. Factores de riesgo. Neumonía.

Correspondence:

*Ivonne A. Roy-García

E-mail: ivonne3316@gmail.com
Gac Med Mex. 2020;156:516-522

Contents available at PubMed

www.gacetamedicademexico.com

0016-3813/@ 2020 Academia Nacional de Medicina de México, A.C.. Published by Permanyer. This is an open access article under the CC BY-NC-ND license (http://creativecommons.org/licenses/by-nc-nd/4.0/). 


\section{Introduction}

In December 2019, an outbreak of pneumonia was described in Wuhan, China, which soon was identified to be caused by a new coronavirus, SARS-CoV-2; the disease was called COVID-19. The number of COVID-19 cases increased and spread outside China, and its rapid expansion drove the World Health Organization to declare it a health emergency on January 30, 2020.

On April 6, the United States reported the admission of 74 children to pediatric intensive care units in 19 states. In a projection in time, it was estimated that in that country there would be 176,190 children infected with SARS-CoV-2 $(52,381$ neonates and children younger than two years of age, 42,857 children between 2 and 11 years, and 80,952 children aged 12 to 17 years). ${ }^{1}$ By the time this document was written, there were few publications about the infection in the pediatric population.

Recent studies suggest that children are as prone as adults to become infected with SARS-CoV-2, but have fewer symptoms and the disease is less severe, ${ }^{2}$ as observed with SARS and MERS-CoV coronaviruses. ${ }^{3,4}$

There are different immunological hypotheses that support the reasons why children have fewer complications. One of the most interesting is that related to the angiotensin-converting enzyme 2 (ACE2) receptor, which is a binding site for SARS-CoV-2. ${ }^{5}$. It has been postulated that children have fewer ACE2 receptors and, consequently, a lower affinity in comparison with adults, which is why they could be less affected. Another hypothesis is that children are less affected because mortality has been related to comorbidity. ${ }^{6,7}$ Given that children have few comorbidities, it is expected for them to have lower morbidity and mortality; however, Mexico is one of the countries with the highest prevalence of childhood obesity, which brings along a significant number of patients with diabetes, cardiovascular risk, and chronic kidney disease ${ }^{8}$ and, therefore, mortality could be high.

Analyzing the causes of SARS-CoV-2-associated mortality in the Mexican pediatric population and its related factors will allow improving decision-making in clinical practice.

\section{Method}

A secondary analysis of the database generated by the General Directorate of Epidemiology, corresponding to the Ministry of Health of Mexico, was carried out. This is an open database that is updated on a daily basis with the reports of suspected and confirmed cases by a SARS-CoV-2 positive test performed by the National Institute for Epidemiological Diagnosis and Reference (https://www.gob.mx/salud/documentos/datos -abiertos-152127).

The database, which included 215,656 patients diagnosed with COVID-19, updated to May 23, 2020, was downloaded. The database includes the following variables: identification record, origin (in or outside Respiratory Disease Monitoring Health Units, unspecified), sector (health or private sector), state, medical unit, gender (male or female, not specified), state of birth, state of residence, municipality, type of patient (outpatient, hospitalized, not specified), whether the patient is indigenous language speaker, nationality (Mexican, foreign, not specified), date of admission, date of symptoms onset, death date (if applicable), whether the patient is intubated (on mechanical ventilation), presence of pneumonia, age, diabetes, asthma, immunosuppression, systemic hypertension, cardiovascular comorbidity, obesity, chronic kidney disease, SARS-CoV-2 test result (positive, non-positive, pending) and whether the patient was attended to at any intensive care unit.

Patients younger than 18 years of age, diagnosed with COVID-19 by SARS-CoV-2 detection using the real-time polymerase chain reaction (RT-PCR) test, were selected.

Of the above-mentioned variables, type of patient, date of death, age $\leq 18$ years, diabetes, asthma, immunosuppression, systemic hypertension, high cardiovascular risk, obesity, chronic kidney disease, if care was provided in a pediatric intensive care unit and if intubation (mechanical ventilation) was required, were included. These data were recorded by the treating physicians.

\section{Statistical analysis}

The database was cleansed to look for aberrant data; age was replaced with a gender-adjusted linear regression model in 10 patients. Qualitative variables (diabetes, asthma, obesity, cardiovascular risk and chronic kidney disease) showed less than $0.5 \%$ of missing values, which were replaced by the mode. The mortality variable was not imputed.

Descriptive statistics were calculated. To assess whether the age variable had a normal distribution, mental tests were first used to determine whether the median was within the mean confidence intervals; if it 
Table 1. General characteristics of the pediatric population diagnosed with COVID-19

\begin{tabular}{|c|c|c|c|c|}
\hline \multirow[t]{2}{*}{ Variable } & \multicolumn{2}{|c|}{ Suspected $(n=11,405)$} & \multicolumn{2}{|c|}{ Confirmed $(n=1,443)$} \\
\hline & Median & IQR & Median & IQR \\
\hline \multirow[t]{2}{*}{ Age $\left(\right.$ years) ${ }^{*}$} & 8 & $(3-14)$ & 12 & $(5,16)$ \\
\hline & $\mathrm{n}$ & $\%$ & $\mathrm{n}$ & $\%$ \\
\hline Male gender ${ }^{\star *}$ & 5,430 & $(47.6)$ & 693 & $(48)$ \\
\hline Pneumonia** & 1,683 & $(14.8)$ & 141 & $(9.8)$ \\
\hline Diabetes** & 91 & $(0.8)$ & 16 & $(1.1)$ \\
\hline Asthma** & 479 & $(4.2)$ & 49 & (3.4) \\
\hline Immunosuppression** & 478 & $(4.2)$ & 46 & (3.2) \\
\hline Chronic kidney disease ${ }^{\star *}$ & 95 & $(0.8)$ & 13 & $(0.9)$ \\
\hline High cardiovascular risk ${ }^{* *}$ & 220 & (1.9) & 21 & $(1.5)$ \\
\hline Obesity** & 341 & (3) & 82 & $(5.7)$ \\
\hline Tobacco use ${ }^{* *}$ & 118 & (1) & - & - \\
\hline Intensive care unit admission ${ }^{\star \star}$ & 412 & (3.6) & 48 & (3.3) \\
\hline Intubation** & 294 & (2.6) & 26 & (1.8) \\
\hline Death** & 165 & (1.4) & 27 & (1.9) \\
\hline
\end{tabular}

${ }^{*}$ Comparison with Mann-Whitney's U-test. * ${ }^{*}$ Comparison with chi-square test.

Data highlighted in bold show a p-value $<0.05$

was symmetric and asymptotic, it was corroborated with the Kolmogorov-Smirnov test, with a $p$-value $>0.05$ being assumed as normal. By means of these tests, the age that had a free distribution was defined, and thus it was summarized as the median and interquartile range (IQR; $25-75 \%$ ). The rest of qualitative variables were summarized as frequencies and percentages.

A bivariate model was constructed, where Pearson's chi-square was used; to assess variables' clinical significance and relevance, relative risks (RR) with $95 \%$ confidence intervals $(\mathrm{Cl})$ were calculated.

For the multivariate models, the variables that were significant in the bivariate model were used, and another clinical model was constructed where the obesity variable was incorporated, with the purpose to adjust for the main confounding variable published in world literature. The R software and SPSS software version 25 were used for statistical analysis. All statistical inferences were bilateral (two-tailed).

\section{Results}

Eleven thousand four hundred and five children with clinical data suggestive of COVID-19 were studied, out of which 1,443 (12.6\%) were positive in the RT-PCR test. General characteristics of both populations are summarized in table 1.

When the characteristics of the children with a confirmed SARS-CoV-2 diagnosis were analyzed, we found a median age of eight years (IQR: 3-14); the predominant gender was female. Pneumonia was present in $9.8 \%, 3.2 \%$ had a history of immunosuppression, $3.3 \%$ were admitted to a pediatric intensive care unit and $1.8 \%$ required intubation and mechanical ventilation. Mortality was $1.9 \%$ in comparison with $1.4 \%$ of children in whom the diagnosis was not confirmed. SARS-CoV-2-positive children were statistically older, had a lower frequency of pneumonia and a higher percentage of obesity ( $3 \%$ vs. $5.7 \%$ ).

Table 2 shows the risk factors for mortality in patients with a positive RT-PCR test; the main ones were age younger than four years, pneumonia, immunosuppression, and cardiovascular risk, with RRs of 3.8 , 53.1, 10.6 and 5.4, respectively. The rest of the variables showed no statistically significant results, as shown in figure 1.

Table 3 describes the multivariate model, where the variables that were significant in the bivariate model were included and death was considered as a dependent variable. Age, immunosuppression, and 
Table 2. Relative risk for predicting mortality in patients with confirmed COVID-19. Bivariate model

\begin{tabular}{|c|c|c|c|c|c|c|c|}
\hline \multirow[t]{2}{*}{ Variable } & \multicolumn{2}{|c|}{ Dead $(n=27)$} & \multicolumn{2}{|c|}{ Alive $(n=1416)$} & \multirow[t]{2}{*}{ RR } & \multicolumn{2}{|c|}{$95 \%$ confidence interval (for RR } \\
\hline & $n$ & $\%$ & $n$ & $\%$ & & Lower limit & Upper limit \\
\hline Age $<4$ years & 14 & 51.9 & 299 & 21.1 & 3.88 & 1.847 & 8.185 \\
\hline Male gender & 12 & 44.4 & 681 & 48.1 & 0.86 & 0.41 & 1.84 \\
\hline Pneumonia & 23 & 85.2 & 118 & 8.3 & 53.1 & 18.62 & 151.3 \\
\hline Diabetes & 0 & 0 & 16 & 1.1 & NC & - & - \\
\hline Asthma & 0 & 0 & 49 & 3.5 & NC & - & - \\
\hline Immunosuppression & 7 & 26 & 39 & 2.8 & 10.6 & 4.7 & 23.9 \\
\hline Chronic kidney disease & 0 & 0 & 13 & 1 & $\mathrm{NC}$ & - & - \\
\hline High cardiovascular risk & 2 & 7.4 & 19 & 1.3 & 5.4 & 1.4 & 21.4 \\
\hline Obesity & 3 & 11.1 & 79 & 5.6 & 2.1 & 0.64 & 6.75 \\
\hline Intensive care unit admission & 7 & 26 & 41 & 16.7 & 1.63 & 0.73 & 3.6 \\
\hline Intubation & 12 & 44.4 & 14 & 0.9 & 7.6 & 3.99 & 14.5 \\
\hline
\end{tabular}

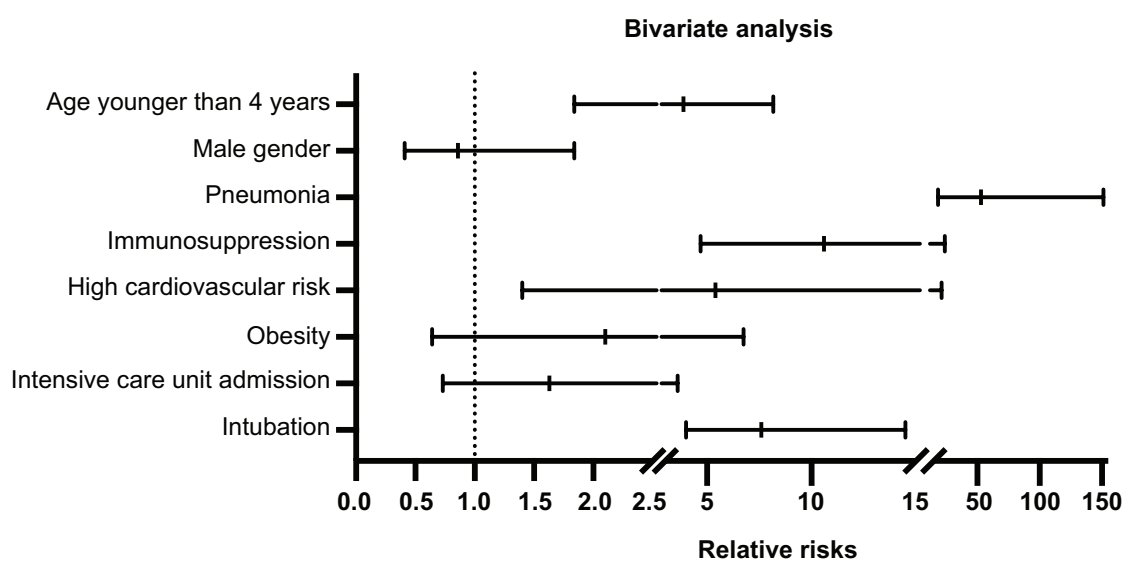

Figure 1. Bivariate model of mortality risk in patients with confirmed COVID-19.

cardiovascular risk did not show to be statistically independent factors related to death.

The development of pneumonia was an independent risk factor, with an odds ratio (OR) of 6.45 (95\% Cl: $1.99,20.89$ ), and intubation (use of mechanical ventilation) had an OR of 8.75 (95\% Cl: $3.23,23.7)$.

The model adjusted according to obesity showed that this variable had no significant effect in the multivariate model, as observed in figure 2 .

\section{Discussion}

Herein, we present general values of morbidity and mortality in the Mexican pediatric population with
COVID-19, which is information that was obtained thanks to the efforts of Mexican doctors and the Ministry of Health of Mexico, which made the data accessible for analysis and publication.

During the first semester of the pandemic, $27 \mathrm{de}$ ceased children were recorded, with a mortality rate of $1.9 \%$. This is the highest figure reported in the world, higher than that of the United States, with 26 children, and the United Kingdom, with 15 cases, and contrasts with mortality in South Korea, where no cases were recorded. ${ }^{9-14}$ Undoubtedly, this high mortality should alert the population, the pediatric associations and the Ministry of Health itself. 
Table 3. Multivariate analysis of the main risk factors associated with mortality in children with COVID-19

\begin{tabular}{|c|c|c|c|c|c|c|c|}
\hline \multirow[t]{2}{*}{ Variable } & \multicolumn{5}{|c|}{ Deceased children $(n=27)$} & \multicolumn{2}{|c|}{$95 \%$ confidence interval (for OR) } \\
\hline & Median & (IQR) & B & SE & OR & Lower & Upper \\
\hline \multirow[t]{2}{*}{ Age, years } & 3 & $1-14$ & 0.006 & 0.034 & 1.01 & 0.940 & 1.07 \\
\hline & n & $\%$ & B & SE & OR & Lower & Upper \\
\hline Pneumonia & 23 & 85.2 & 1.87 & 0.59 & 6.45 & 1.99 & 20.89 \\
\hline Immunosuppression & 7 & 26 & 0.98 & 0.56 & 2.66 & 0.88 & 8.03 \\
\hline High cardiovascular risk & 2 & 7.4 & 1.15 & 0.92 & 3.1 & 0.52 & 19.1 \\
\hline Intubation & 12 & 44.4 & 2.17 & 0.63 & 8.75 & 3.23 & 23.7 \\
\hline
\end{tabular}

$\mathrm{SE}=$ standard error, $\mathrm{OR}=$ odds ratio, $\mathrm{IQR}=$ interquartile range $25-75 \%$.

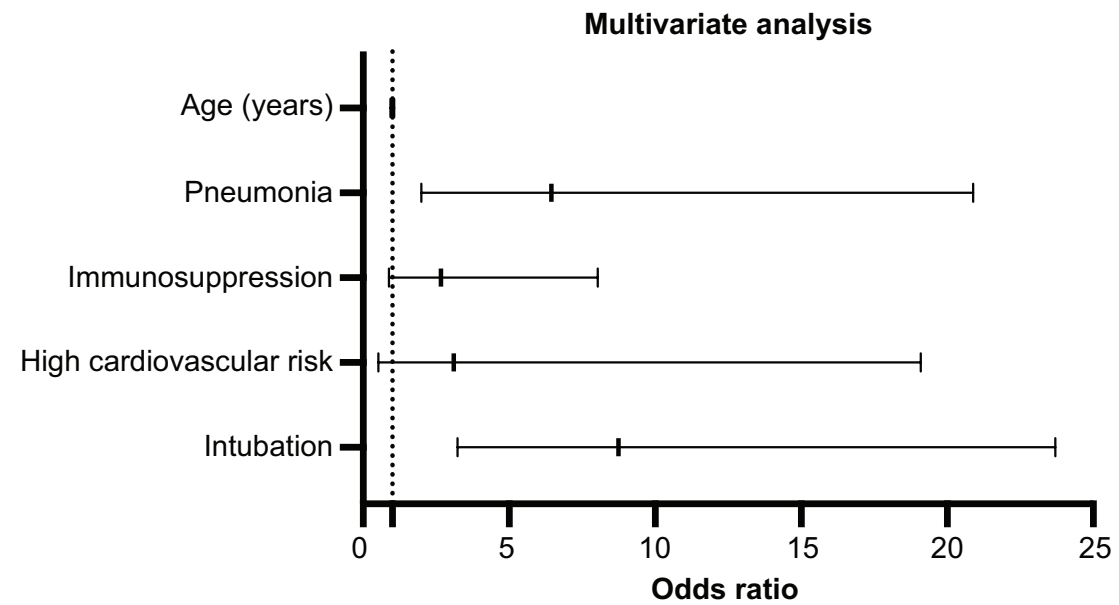

Figure 2. Results of the multivariate model of children with COVID-19, where the dependent variable was death.

In this study, 11,405 children had a diagnosis suggestive of COVID-19, which was confirmed in 1,443 children (12.6\%), out of whom 1,416 had mild symptoms and were treated on an outpatient basis, $3.3 \%$ were admitted to intensive care units and 1.8 $\%$ required mechanical assistance for ventilation. Mexican children had a more torpid evolution than in series reported in other countries ${ }^{15,16}$

Unlike observations described in influenza, where schoolchildren are considered the main drivers of transmission of the disease,$^{17}$ in the COVID-19 pandemic, children do not play an important role in transmission, since a low rate of attack has been observed $(\mathrm{OR}=0.23$ in comparison with that of adults older than 60 years), and family studies have recorded that only in $5 \%$ of cases the index case is a child. ${ }^{18}$ Moreover, given that symptomatology in this population group is mild, their viral load is usually low. ${ }^{19}$ These data are important for planning the return to school activities.

In a series of 25 children in China, no cases of severe COVID-19 were found. In this small series, all patients were reported to have been discharged without complications..$^{20}$ In our study, we found that mortality affected $1.9 \%$ of SARS-CoV-2-infected children, among whom the most affected were those with any type of immunocompromise or cardiovascular risk. This corroborates published data, which estimate that $3 \%$ will be admitted to intensive care units; in our study, $43(3.3 \%)$ required admission to a pediatric

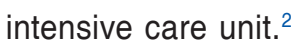

Another series of nine cases reported in China referred that pneumonia was the most serious manifestation; none of the children required intubation or died. ${ }^{21}$ The differences between these small series perhaps are due to the sample size or differences in 
the child population between countries. In Mexico, we showed that pneumonia occurs in $9.8 \%$ of the population of patients with COVID-19. However, pneumonia occurrence is not higher than that observed in children without COVID-19, who have a higher incidence $(14.1 \%)$. We should not forget that the beginning of the pandemic coincided with the end of the winter season, in which respiratory infections associated with other etiological agents such as influenza and respiratory syncytial virus are common. This may be the reason for the similarity of the figures for COVID-19 and non-COVID-19 pneumonia in the pediatric population of Mexico. Ground-glass radiological image has been reported to be observed in up to $30 \%$ of patients without clinical pneumonia, ${ }^{22}$ which is why the relevance of radiological imaging for establishing the pneumonia diagnosis should be defined.

Although pneumonia does not occur with a higher frequency in SARS-CoV-2-positive patients, it is more aggressive and increases 52 times the risk of dying than when it does not develop. Undoubtedly, this information is crucial, since in the absence of effective drugs against SARS-CoV-2, it is imperative to closely monitor oxygen requirements, seek the best mechanical ventilatory support strategy, identify inflammation markers, perform cultures and identify other respiratory pathogens that might complicate COVID-19 clinical picture. In a cohort of Chinese children, an European multicenter study, and a world-wide meta-analysis, the percentage of coinfections was 5.6, 5, and $6 \%$, respectively. ${ }^{9,15,21}$

Although there are no clinical trials validating any specific pharmacological strategy, daily human cost of the disease increases day by day, which is why starting the use of empirical treatments that are not fully tested, such as antimalarials, ivermectin, nitazoxanide, azithromycin and antiretroviral drugs, is necessary. ${ }^{23}$

An aspect that stands out among our results, is the absence of a relationship between obesity and mortality, a common association in adults, but rarely reported in children; in a cohort of children in the United States, it was recorded as the main comorbidity (22 \%), ${ }^{24}$ and in $15 \%$ of children admitted to intensive care units for COVID-19 in the European Union and Canada. ${ }^{11}$ Interestingly, only in $5.7 \%$ was obesity found in this study, which is a lower prevalence than that reported in the Mexican child population, estimated at $35 \%$. This can be attributed to the fact that this condition was not recorded while under the care of the emergency department.
One strength of our research was the source of information. The General Directorate of Epidemiology database integrates information of all patients attended to at medical units of the Mexican Republic, which offers data that can be analyzed in order to give rise to specific investigations, with sample size calculation and better designs, that corroborate new hypotheses.

One weakness of this database is that it contains limited clinical information, which might even not be accurate, such as obesity diagnosis or immunosuppression or cardiovascular risk definitions, which favors performance biases. Nevertheless, it allows issuing the first prognoses of the disease and showing causal associations with mortality, such as the development of pneumonia. These data are necessary for a better understanding of COVID-19 and for improving the treatment provided to pediatric patients; ${ }^{25}$ furthermore, we could consider these data a reflection of current care and outcomes in Mexico.

\section{Conclusions}

Children with COVID-19 have lower mortality than adults; however, SARS-CoV-2 infection is not benign and can have fatal consequences. In children with COVID-19, special attention should be paid to avoiding pneumonia; timely diagnosis and treatment, especially in children younger than four years of age, with cardiovascular risk or immunosuppressed, might help reduce mortality.

\section{Conflicts of interest}

The authors declare that they have no conflicts of interest.

\section{Funding}

The authors did not receive any sponsoring to carry out this article.

\section{Ethical disclosures}

Protection of human and animal subjects. The authors declare that the procedures that were followed adhered to the ethical standards of the responsible human experimentation committee and were in agreement with the World Medical Association and the Declaration of Helsinki. 
Confidentiality of data. The authors declare that they have followed the protocols of their work center on the publication of patient data.

Right to privacy and informed consent. No data that violate the privacy or rights of patients are disclosed in this document.

\section{References}

1. Pathak EB, Salemi JL, Sobers N, Menard J, Hambleton IR. COVID-19 in children in the United States: intensive care admissions, estimated total infected, and projected numbers of severe pediatric cases in 2020 J Public Health Manag Pract. 2020;26:325-333.

2. Zimmermann P, Curtis N. COVID-19 in children, pregnancy and neonates: a review of epidemiologic and clinical features. Pediatr Infect Dis J. 2020;39:469-477.

3. Leung C, Kwan Y, Ko P, Chiu SS, Loung P, Fong N, et al. Severe acute respiratory syndrome among children. Pediatrics. 2004;113:E535-543.

4. Al-Tawfiq JA, Kattan RF, Memish ZA. Middle East respiratory syndrome coronavirus disease is rare in children: An update from Saudi Arabia. World J Clin Pediatr. 2016;5:391.

5. Letko M, Marzi A, Munster V. Functional assessment of cell entry and receptor usage for SARS-CoV-2 and other lineage $B$ betacoronaviruses. Nat Microbiol. 2020;5:562-569.

6. Patel $A B$, Verma A. COVID-19 and angiotensin-converting enzyme inhibitors and angiotensin receptor blockers: what is the evidence? JAMA. 2020;323:1769-1770.

7. Patel AB, Verma A. Nasal ACE2 levels and COVID-19 in children. JAMA 2020:323:2386-2387.

8. Shamah-Levy T, Cuevas-Nasu L, Gaona-Pineda EB, Gómez-Acosta LM, Morales-Rúan MDC, Hernández-Ávila M, et al. Sobrepeso y obesidad en niños y adolescentes en México, actualización de la Encuesta Nacional de Salud y Nutrición de Medio Camino 2016. Salud Publica Mex. 2018;60:244.

9. Hoang A, Chorath K, Moreira A, Evans M, Burmeister-Morton F, Burmeister F, et al. COVID-19 in 7780 pediatric patients: a systematic review. EClinicalMedicine. 2020;24:100433.

10. Castagnoli R, Votto M, Licari A, Brambilla I, Bruno R, Perlini S, et al. Severe acute respiratory syndrome coronavirus 2 (SARS-CoV-2) infection in children and adolescents: a systematic review. JAMA Pediatr. 2020;174:882-889.
11. Shekerdemian LS, Mahmood NR, Wolfe KK, Riggs BJ, Ross CE, McKiernan CA, et al. Characteristics and outcomes of children with coronavirus disease 2019 (COVID-19) infection admitted to US and Canadian pediatric intensive care units. JAMA Pediatr. 2020;174:1-6.

12. Korean Society of Infectious Diseases, Korean Society of Pediatric Infectious Diseases, Korean Society of Epidemiology, Korean Society for Antimicrobial Therapy, Korean Society for Healthcare-associated Infection Control and Prevention, Korean Centers for Disease Control and Prevention. Report on the epidemiological features of coronavirus disease 2019 (COVID-19) outbreak in the republic of Korea from January 19 to March 2, 2020. J Korean Med Sci. 2020;35:1-11.

13. Bialek S, Gierke R, Hughes M, McNamara LA, Pilishvili T, Skoff T. Coronavirus disease 2019 in children - United States, February 12-April 2, 2020. MMWR Morb Mortal Wkly Rep. 2020;69:422-426.

14. Khan EA. COVID-19 in children: epidemiology, presentation, diagnosis and management. J Pak Med Assoc. 2020;70:S108-S112.

15. Götzinger F, Santiago-García B, Noguera-Julián A, Lanaspa M, Lancella L, Calò Carducci FI, et al. COVID-19 in children and adolescents in Europe: a multinational, multicentre cohort study. Lancet Child Adolesc Health. 2020;4:1-9.

16. Dong $Y$, Mo X, Hu Y, Qi X, Jiang F, Jiang Z, et al. Epidemiology of COVID-19 among children in China. Pediatrics. 2020;145:e20200702.

17. Neuzil KM, Hohlbein C, Zhu Y. Illness among schoolchildren during influenza season. Arch Pediatr Adolesc Med. 2002;156:986-991.

18. Munro APS, Faust SN. Children are not COVID-19 super spreaders: time to go back to school. Arch Dis Child. 2020;105:618-619.

19. Ludvigsson JF. Children are unlikely to be the main drivers of the COVID-19 pandemic - a systematic review. Acta Paediatr. 2020;109:1-6.

20. Bai K, Liu W, Liu C, Fu Y, Hu J, Qin Y, et al. Clinical analysis of 25 COVID-19 infections in children. Pediatr Infect Dis J. 2020;39:e100-e103.

21. Su L, Ma X, Yu H, Zhang Z, Bian P, Han Y, et al. The different clinical characteristics of corona virus disease cases between children and their families in China-the character of children with COVID-19. Emerg Microbes Infect. 2020;9:707-713.

22. Lu X, Zhang L, Du H, Zhang J, Li YY, Qu J, et al. SARS-CoV-2 infection in children. N Engl J Med. 2020;382:1663-1665.

23. Sanders JM, Monogue ML, Jodlowski TZ, Cutrell JB. Pharmacologic treatments for coronavirus disease 2019 (COVID-19): a review. JAMA. 2020;323:1824-1836.

24. Zachariah P, Johnson CL, Halabi KC, Ahn D, Sen Al, Fischer A, et al. Epidemiology, clinical features, and disease severity in patients with coronavirus disease 2019 (COVID-19) in a children's hospital in New York City, New York. JAMA Pediatr. 2020;2019:e202430.

25. She J, Liu L, Liu W. COVID-19 epidemic: disease characteristics in children. J Med Virol. 2020;92:747-754. 